\title{
Identifying Contractors' Planned Quality Costs in Indonesian Construction Projects ${ }^{1}$
}

\author{
Puti F. Marzuki ${ }^{1} \&$ M. Wisridani ${ }^{2}$ \\ ${ }^{1}$ Construction Engineering \& Management Research Group \\ Institut Teknologi Bandung, Jl. Ganesa No. 10, Bandung 40132, Indonesia \\ ${ }^{2}$ PT. Rekadaya Elektrika, Jl. Tanjung Karang No.3-4A, Jakarta 10230, Indonesia \\ Email: puti@si.itb.ac.id
}

\begin{abstract}
In a very competitive construction industry, quality costs have to be measured to be able to identify potential quality problem areas and to focus attention on work output improvement opportunities. The awareness of contractors on the importance of quality costs could be reflected in the extent of their quality costs planning. This paper presents an identification of planned quality costs in three construction projects executed by two large Indonesian contractors, a state-owned company and a private company in Jakarta. The objective is to enable the contractors to elaborate their quality costs planning and thereby improve their work output based on the findings. Quality costs are first grouped into three categories: prevention, appraisal, and failure costs. Based on the works of previous researchers, a list of quality management activities that should be covered in each quality costs category is then created. The contractors' planned quality costs data for each category are identified and collected through interviews and questionnaire surveys that refer to the list. Quality costs are expressed as a percentage of contract value. It is revealed that although large contractors already have certain knowledge on quality costs in construction projects, these costs are not planned in a structured way through an analysis of systematic quality costs records. Through cost categorization it is also shown that higher prevention and appraisal costs lead to lower failure costs. It is then concluded that a lot of work is still to be done by the contractors to set up a quality costs recording system which can serve as a basis for their quality improvement planning.
\end{abstract}

Keywords: appraisal costs; construction projects; contractors; failure costs; prevention costs; quality costs.

\section{Introduction}

Facing the challenge of competitiveness, most large Indonesian contractors have a quality management system and are ISO 9001 certified. However, to be able to produce quality work output a quality management system has to be

\footnotetext{
1) This paper is a development of an initial work 'Quality Cost in Indonesian Construction Projects' presented in the Proceeding of the $2^{\text {nd }}$ International Conference on Sustainable Infrastructure \& Built Environment (SIBE) under the same authors. In-depth analysis and discussion have been provided to have more elaborate perspective and conclusion.

Received April $18^{\text {th }}, 2014,1^{\text {st }}$ Revision August $18^{\text {th }}, 2014,2^{\text {nd }}$ Revision September $1^{\text {st }}, 2014$, Accepted for publication September $16^{\text {th }}, 2014$.

Copyright (C) 2014 Published by ITB Journal Publisher, ISSN: 2337-5779, DOI: 10.5614/j.eng.technol.sci.2014.46.4.2
} 
successfully applied. The measurement of quality costs is thought to be one of the most effective ways for evaluating the success of a quality management system. Quality costs include, costs related to implementing quality activities and costs that are endured due to poor quality.

Thus, in construction projects, contractors need to plan and allocate their quality costs budget for quality-related endeavors in the implementation of their quality management system. Although rather difficult to carry out, this budget should be planned based on quality costs measurements, and in this context the process is called quality costs planning. This paper identifies planned quality costs in the execution of three construction projects by two large Indonesian contractors in Jakarta. The objective is to enable the contractors to elaborate their quality costs planning and thereby improve their work output based on the findings.

\section{$2 \quad$ Literature Review}

Dale and Oakland [1] were among the researchers who had defined qualityrelated costs. According to them these costs are those incurred in the design, implementation, operation, maintenance of an organization's quality system, as well as the cost of organizational resources committed to the process of continuous improvement, plus those costs incurred owing to failures of the systems, products and services. Quality and its costs have to be measured. In this regard, Dale and Plunkett [2] stated that measuring quality costs is needed because such measurements focused attention on areas of high expenditure and wastage and identified potential problem areas, cost-reductions and improvement opportunities. Quality costs recorded data will serve in the planning of quality costs of future works which have to be covered by the organizations' budget.

Recognizing the need to categorize quality costs, so to be able to use them as a means of quantifying the benefits of adopting a total quality management approach, Feigenbaum [3] broke down quality costs into prevention, appraisal, and failure costs. Prevention cost covers expenses incurred for preventing the production of defective products. Appraisal cost is the cost incurred in appraising the condition of a product or material with reference to specification. Internal failure cost is the cost arising from defective units produced that are detected within a plant, while external failure cost is the cost arising from defective products reaching the customer. Crosby [4] later suggested categorizing costs of quality into conformance and non-conformance costs.

Aoieong [5] mentioned that the manufacturing industry has been applying the concept of using quality costs as a tool to measure quality for quite a long time. Later on, with increasing awareness of the importance of continuous 
improvement, the construction industry has started to recognize a need for a quality and quality costs measurement which can further reflect the performance of a quality management system. Several researchers including Love and Irani [6], Aoieong [5], and Abramsson, et al. [7] had suggested quality management activities in construction projects that should be considered in each category of quality costs.

The importance of quality costs in construction projects had been mentioned by a number of researchers. Tawfek, et al. [8], for example, stated that the cost of quality is an essential part of the total cost of any construction project. Lam, et al. [9] suggested that quality costs could make up, on average $8 \%$ to $15 \%$ of the total construction cost. Abdul-Rahman [10] stated that the effect of poor quality on construction cost can be significant. However, it is usually overlooked by contractors. Aoieong [5] stated that one of the reasons why quality costing received less attention in the construction industry was probably due to the complexity of the construction processes, hence making the measurement of quality costs rather difficult. According to Abramsson, et al. [7], an acute lack of information is identified to be one of the main causes of difficulties in measuring quality cost.

Although rather difficult to implement, quality costs recording, measurement and analysis in construction should have been considered as a necessity. Once quality costs have been elaborately measured and recorded, the planning of quality costs for improvement actions in future projects would be facilitated.

\section{$3 \quad$ Methodology}

Based on Feigenbaum's theory, in this research construction quality costs are categorized as follows: 1) Prevention cost: expenses incurred for preventing the delivery of defective construction work; 2) Appraisal cost: the cost incurred in appraising the condition of construction work with reference to specification; 3 ) Failure cost: cost arising from defective construction work detected before handing over the completed facility to the client (internal failure cost) and cost arising from defective construction work detected after handing over the facility to the client (external failure cost).

Adopting the works of Love and Irani [6], Aieong [5], and Abramsson, et al. [7], a list of quality management activities that should be covered in each quality costs category is first created (see Table 2, Table 3, and Table 4). Using the list, the contractors' planned quality costs data for each category are then identified and collected through interviews and questionnaire survey. Quality costs are expressed as a percentage of contract value. 
The survey involved two contractors, i.e. Contractor A (state owned company) and Contractor B (private company), who were executing three construction projects in Jakarta. Contractor A was executing two construction projects (Project 1 and Project 2) while contractor B was carrying out one construction project (Project 3) in Jakarta as described in Table 1. Project 1 consisted of the construction of a 5-floor mall and a three-tower apartment building. Each tower had 33 floors. Project 2 consisted of constructing a 10-floor mall, one office tower, and a two-tower apartment building with 40 floors in each apartment tower. Meanwhile in Project 3, a three-tower apartment building was constructed. The contractors had set a quality system based on which quality activities were carried out. These activities were comprised of quality planning, control, and assurance. Each contractor was ISO 9001 certified and had a quality control department in its project organizations.

The respondents of the survey consist of the following project personnel: 1) quality control managers and their staff, and 2) cost control managers and their staff. $53 \%$ of the respondents are from the cost control departments and $47 \%$ are from the quality control departments of the projects. $26 \%$ of the respondents have more than 10 years work experience and $34 \%$ of the respondents have the least work experience (less than 5 years). All of the respondents have engineering education backgrounds (civil engineers, architects, and technicians).

Table 1 Respondents of Questionnaire Survey.

\begin{tabular}{cccc}
\hline Project & Constructed Facility & Contractor & $\begin{array}{c}\text { Number of } \\
\text { Respondents }\end{array}$ \\
\hline 1 & Mall \& Apartment Building & $\begin{array}{c}\text { State-owned company } \\
\text { (Contractor A) }\end{array}$ & 13 \\
2 & Mall, Office \& Apartment & $\begin{array}{c}\text { State-owned company } \\
\text { (Contractor A) } \\
\text { Building }\end{array}$ & 12 \\
3 & Apartment Building & $\begin{array}{c}\text { (Contractor B) } \\
\text { (Company }\end{array}$ & 13 \\
\hline
\end{tabular}

Collected project data related to quality cost budget allocation are then placed under each quality cost category. These data represent each contractor's planned prevention, appraisal, and failure costs for each project. Identified planned costs are measured by the percentage of contract value.

\section{Analysis and Findings}

\subsection{Prevention Cost}

Limited and incomplete prevention cost planning was carried out by the two contractors. Prevention cost elements that were left out by the contractors 
included the costs of contract review, construction method design efficiency, new product testing, quality record review, purchase schedule efficiency, auditor remuneration, supplier/subcontractor review, expertise certification, and quality reporting. Lack of quality cost accounting in each company's system made quality cost measurement rather difficult. Table 2 presents a summary of quality management activities that should be covered by prevention cost and those identified in the three projects based on contractors' plan (activities with $\sqrt{ }$ symbol).

Table 2 Quality Management Activities Covered by Prevention Cost.

\begin{tabular}{|c|c|c|c|c|}
\hline Category & Elements & $\begin{array}{c}\text { Proj. } \\
1\end{array}$ & $\begin{array}{c}\text { Proj. } \\
2\end{array}$ & $\begin{array}{c}\text { Proj. } \\
\mathbf{3}\end{array}$ \\
\hline \multirow[t]{5}{*}{ Quality Planning } & Quality and SHE policy & $\sqrt{ }$ & $\sqrt{ }$ & $\mathrm{X}$ \\
\hline & Project quality plan & $\sqrt{ }$ & $\sqrt{ }$ & $\mathrm{X}$ \\
\hline & Project quality record & $\sqrt{ }$ & $\sqrt{ }$ & $\mathrm{X}$ \\
\hline & Contract evaluation & $\mathrm{X}$ & $\mathrm{X}$ & $\mathrm{X}$ \\
\hline & Construct. method design efficiency & $\mathrm{X}$ & $\mathrm{X}$ & $\mathrm{X}$ \\
\hline \multirow[t]{3}{*}{ Product Review } & Product quality review & $\sqrt{ }$ & $\sqrt{ }$ & $\sqrt{ }$ \\
\hline & Site visit & $\sqrt{ }$ & $\sqrt{ }$ & $\sqrt{ }$ \\
\hline & Product testing & $\mathrm{X}$ & $\mathrm{X}$ & $\mathrm{X}$ \\
\hline \multirow[t]{8}{*}{ Process Control } & ITP documents & $\sqrt{ }$ & $\sqrt{ }$ & $\sqrt{ }$ \\
\hline & QC personnel remuneration & $\sqrt{ }$ & $\sqrt{ }$ & $\sqrt{ }$ \\
\hline & SHE equipment & $\sqrt{ }$ & $\sqrt{ }$ & $\sqrt{ }$ \\
\hline & SHE remuneration & $\sqrt{ }$ & $\sqrt{ }$ & $\sqrt{ }$ \\
\hline & Daily meetings & $\sqrt{ }$ & $\sqrt{ }$ & $\sqrt{ }$ \\
\hline & Quality record review & $\mathrm{X}$ & $\mathrm{X}$ & $\mathrm{X}$ \\
\hline & Weekly meetings & $\sqrt{ }$ & $\sqrt{ }$ & $\sqrt{ }$ \\
\hline & Purchasing schedule efficiency & $\mathrm{X}$ & $\mathrm{X}$ & $\mathrm{X}$ \\
\hline \multirow{3}{*}{ Quality Audit } & Internal quality audit & $\sqrt{ }$ & $\sqrt{ }$ & $\mathrm{X}$ \\
\hline & External quality audit & $\sqrt{ }$ & $\sqrt{ }$ & $\sqrt{ }$ \\
\hline & Auditor remuneration & $\mathrm{X}$ & $\mathrm{X}$ & $\mathrm{X}$ \\
\hline \multirow{3}{*}{$\begin{array}{l}\text { Supplier Quality } \\
\text { Evaluation }\end{array}$} & Procurement staff remuneration & $\sqrt{ }$ & $\sqrt{ }$ & $\sqrt{ }$ \\
\hline & Supplier/subcontractor evaluation & $\mathrm{X}$ & $\mathrm{X}$ & $\mathrm{X}$ \\
\hline & Vendor evaluation & $\mathrm{X}$ & $\mathrm{X}$ & $\mathrm{X}$ \\
\hline \multirow{4}{*}{$\begin{array}{l}\text { Quality Training } \\
\text { Programs }\end{array}$} & Internal trainings & $\sqrt{ }$ & $\sqrt{ }$ & $\sqrt{ }$ \\
\hline & QA/QC certification & $\mathrm{X}$ & $\mathrm{X}$ & $\mathrm{X}$ \\
\hline & Head office training & $\sqrt{ }$ & $\sqrt{ }$ & $\sqrt{ }$ \\
\hline & Skilled labor training & $\sqrt{ }$ & $\sqrt{ }$ & $\sqrt{ }$ \\
\hline \multirow[t]{5}{*}{ Administration } & Remuneration of administrative staff & $\sqrt{ }$ & $\sqrt{ }$ & $\sqrt{ }$ \\
\hline & Quality reporting & $\mathrm{X}$ & $\mathrm{X}$ & $\mathrm{X}$ \\
\hline & Stationery & $\sqrt{ }$ & $\sqrt{ }$ & $\sqrt{ }$ \\
\hline & Assessment & $\sqrt{ }$ & $\sqrt{ }$ & $\sqrt{ }$ \\
\hline & Marketing & $\sqrt{ }$ & $\sqrt{ }$ & $\sqrt{ }$ \\
\hline
\end{tabular}

Figure 1 shows contractor A's allocated prevention cost budget for project 1 expressed in the percentage of contract value. The total allocated budget for 
prevention cost was $0.304 \%$ of contract value. Process control was the element with the highest allocated budget (63.25\% of the total prevention cost). Process control activities included preparation of quality plan and ITP (Inspection and Test Plan) as well as remuneration of required personnel and weekly meetings. By focusing on process control the contractor could expect to reduce the cost of non-conformance and eventually reduce failure cost. Meanwhile, the smallest budget was allocated for quality training program $(0.74 \%$ of the total prevention cost). Some training programs were in fact organized externally by the company's headquarters. A higher budget for prevention cost was allocated in project $2(0.86 \%$ of contract value). Similar elements of prevention cost budget were identified in project 2 (Figure 2). $56.56 \%$ of the prevention cost was allocated to process control which included remuneration of quality control personnel. In project 2 the smallest prevention element budget was allocated to quality audit as its cost was included in the headquarters' spending.

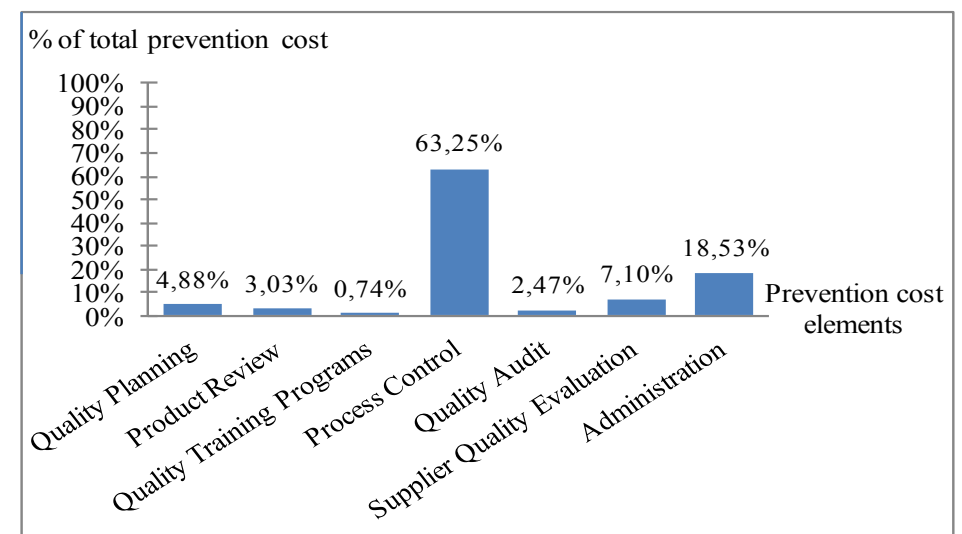

Figure 1 Planned budget allocation for prevention cost elements of project 1.

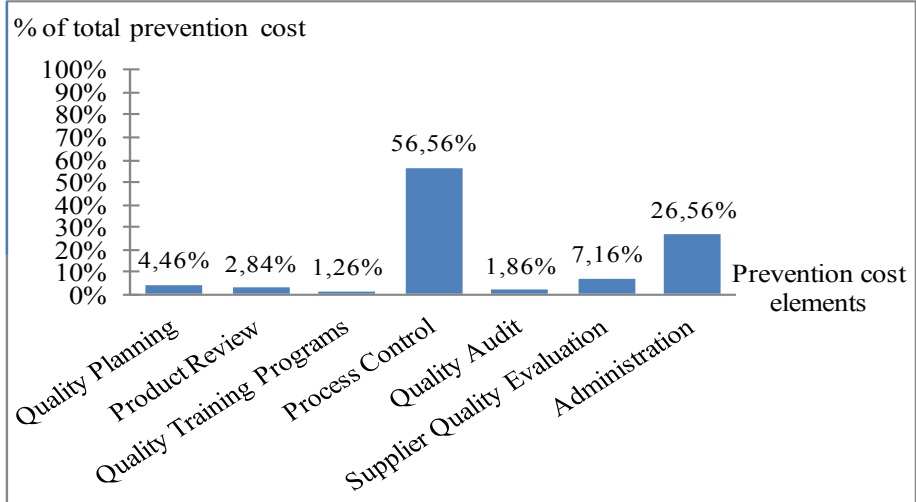

Figure 2 Planned budget allocation for prevention cost elements of project 2. 
Contractor B's allocated budget to cover prevention cost in project 3 was $0.95 \%$ of contract value. Figure 3 shows that the highest amount of this budget was allocated for process control element $(64.04 \%$ of total prevention cost) and the smallest budget was allocated for trainings ( $1.06 \%$ of total prevention cost). Some training programs were also covered by the head office. Internal quality training, as well as training for supervisors and skilled workers, were offered. Meanwhile, nothing was allocated for quality planning and audit planning in this project because activities related to these elements were financed by the company's headquarters.

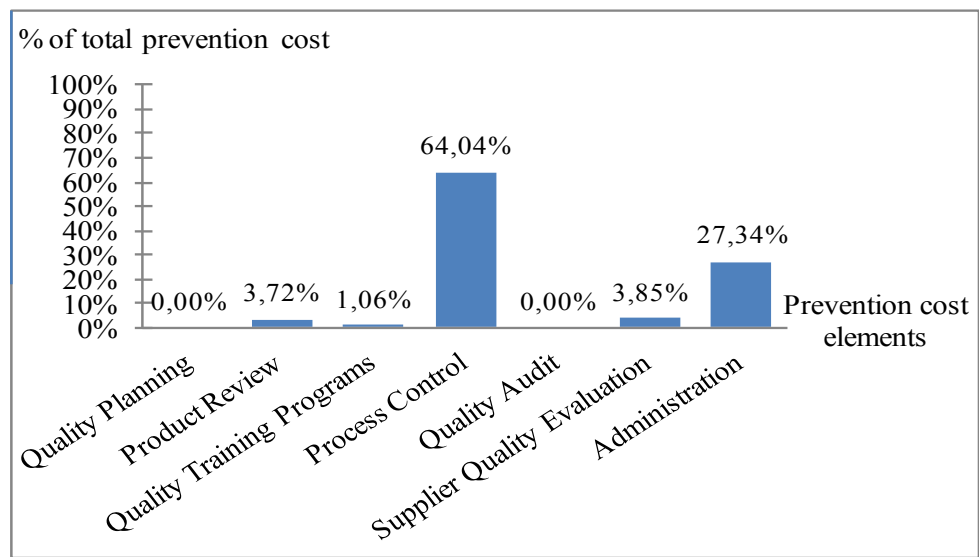

Figure 3 Planned budget allocation for prevention cost elements of project 3 .

\subsection{Appraisal Cost}

Survey results show that with regard to appraisal cost, the contractors had planned their budget allocation in a more detailed and complete way. Only one appraisal cost element, i.e. material plant inspection cost, was still not considered in the plan. Similar to the case of prevention cost, appraisal cost plan was integrated with the overall project cost plan. Table 3 describes quality management activities that should be covered by appraisal cost and the planned appraisal cost of activities (activities with $\sqrt{ }$ symbol) in the three surveyed projects.

Figure 4 depicts the proportion of planned appraisal cost elements of project 1 . The sum of these elements' costs amounted to $0.883 \%$ of contract value. The highest appraisal cost budget was allocated for the inspection and testing process $(74.18 \%$ of the total appraisal cost) and the smallest budget was allocated for test equipment maintenance. Remuneration of supervision personnel was the main item considered in the inspection and testing process. 
Table 3 Quality Management Activities Covered by Appraisal Cost.

\begin{tabular}{ccccc}
\hline Category & Elements & Proj. & Proj. & Proj. \\
& Storage personnel remuneration & $\sqrt{ }$ & $\mathbf{2}$ & $\mathbf{3}$ \\
\hline Material Inspection \& Test & Plant inspection & $\sqrt{ }$ & $\sqrt{ }$ \\
& Laboratory testing & $\sqrt{ }$ & $X$ & $X$ \\
& Material inspection & $\sqrt{ }$ & $\sqrt{ }$ & $\sqrt{ }$ \\
& Stock evaluation & $X$ & $X$ & $X$ \\
Product Quality Inspection & Site testing & $\sqrt{ }$ & $\sqrt{ }$ & $\sqrt{ }$ \\
& Supervisor remuneration & $\sqrt{ }$ & $\sqrt{ }$ & $\sqrt{ }$ \\
& QC remuneration & $\sqrt{ }$ & $\sqrt{ }$ & $\sqrt{ }$ \\
& Supervisor \& inspector remuneration & $\sqrt{ }$ & $\sqrt{ }$ & $\sqrt{ }$ \\
Test Equip. Maintenance & CM supervision \& inspection & $\sqrt{ }$ & $\sqrt{ }$ & $\sqrt{ }$ \\
& Designer supervision \& inspection & $\sqrt{ }$ & $\sqrt{ }$ & $\sqrt{ }$ \\
& Personnel remuneration & $\sqrt{ }$ & $\sqrt{ }$ & $\sqrt{ }$ \\
\hline
\end{tabular}

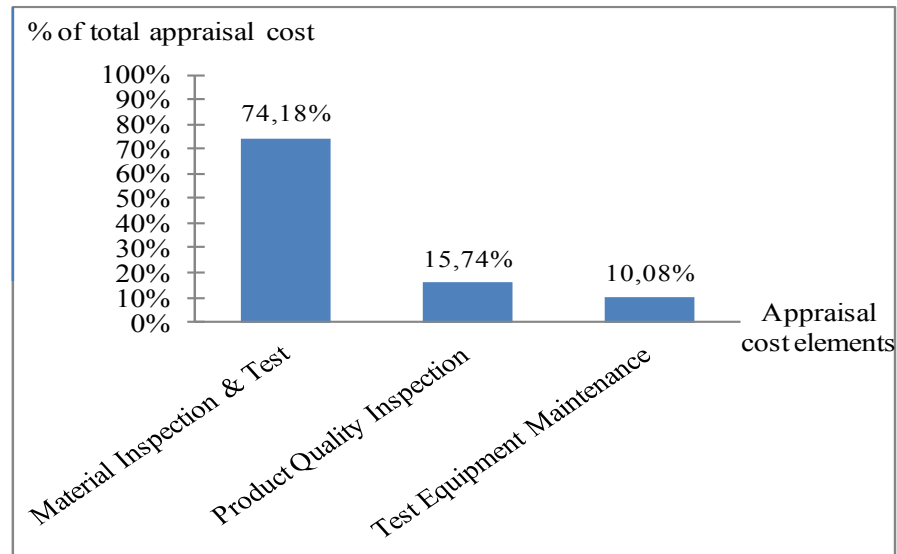

Figure 4 Planned budget allocation for appraisal cost elements of project 1.

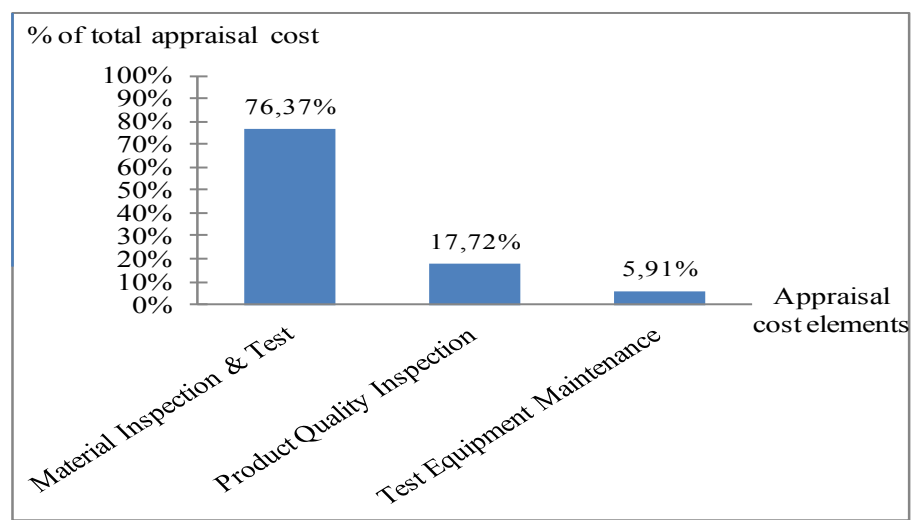

Figure 5 Planned budget allocation for appraisal cost elements of project 2. 
The identified allocated appraisal cost budget for project 2, carried out by the same contractor as project 1, is shown in Figure 5. The total allocated budget was $1.790 \%$ of contract value. Similar to project 1 , the highest budget was allocated for inspection and test process ( $76.37 \%$ of the total appraisal cost), in which the biggest portion was dedicated to remuneration of supervision personnel, and the smallest budget was allocated for test equipment maintenance $(5.91 \%)$.

Meanwhile, in project 3, which was carried out by a private company, a higher portion of project budget was allocated to cover appraisal cost $(2.32 \%$ of contract value) but almost the same percentage of this budget was allocated for the inspection test process $(76.44 \%)$ and for test equipment maintenance $(5.96 \%)$. A large part of the inspection test process budget covered remuneration of supervision personnel. Figure 6 depicts the planned budget allocation for appraisal cost elements of project 3 .

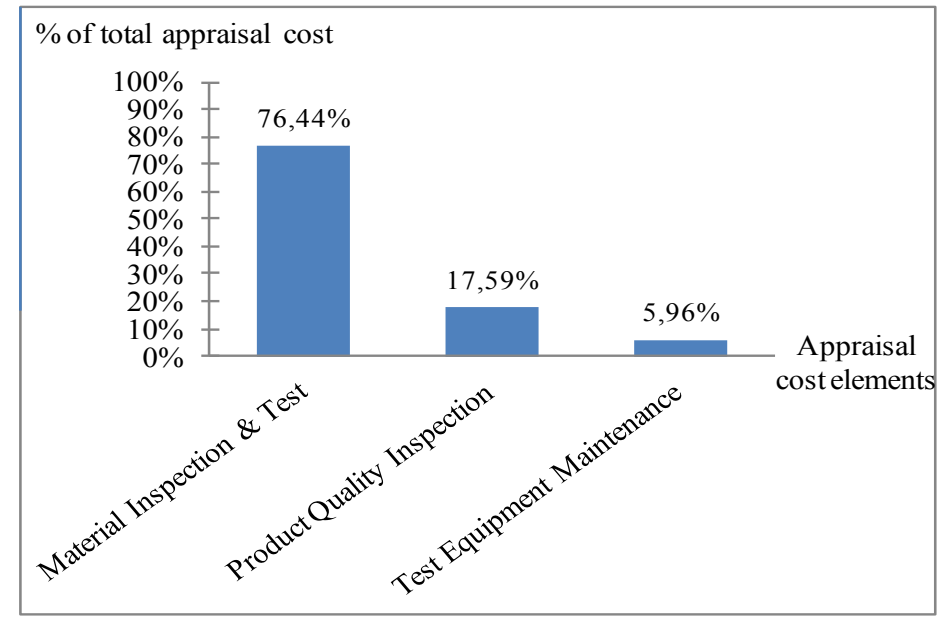

Figure 6 Planned budget allocation for appraisal cost elements of project 3.

\subsection{Failure Cost}

Internal failure cost in this research comprises all of contractor's spending to rectify all defects and flaws of construction during the commissioning process. Survey results show that no budget was planned by either contractors to cover this cost. The amount of this cost was identified after project completion. It is also revealed that detailed and elaborate records of this cost is not available. Table 4 presents a summary of quality management activities that should be covered by internal failure cost, and those identified in the three surveyed projects. 
Table 4 Quality Management Activities Covered by Internal Failure Cost.

\begin{tabular}{ccccc}
\hline Category & Elements & Proj. & Proj. & Proj. \\
\hline Rework & Design revision & $\mathbf{1}$ & $\mathbf{2}$ & $\mathbf{3}$ \\
& Defective product rework & $\mathrm{X}$ & $\mathrm{X}$ & $\mathrm{X}$ \\
& Overtime \& consumables & $\sqrt{ }$ & $\sqrt{ }$ & $\sqrt{ }$ \\
& Retesting & $\mathrm{X}$ & $\mathrm{X}$ & $\mathrm{X}$ \\
Scrap & Material wasted & $\sqrt{ }$ & $\sqrt{ }$ & $\sqrt{ }$ \\
Failure Analysis & Expert remuneration & $\mathrm{X}$ & $\mathrm{X}$ & $\mathrm{X}$ \\
Material Review & Material review & $\mathrm{X}$ & $\mathrm{X}$ & $\mathrm{X}$ \\
Hidden Cost & Lost time & $\mathrm{X}$ & $\mathrm{X}$ & $\mathrm{X}$ \\
& Additional inspection & $\mathrm{X}$ & $\mathrm{X}$ & $\mathrm{X}$ \\
& Additional testing & $\mathrm{X}$ & $\mathrm{X}$ & $\mathrm{X}$ \\
\hline
\end{tabular}

In project 1 , it was found that this cost was comprised of rework cost $(33.33 \%$ of the total internal failure cost) and the cost of scrap (66.67\% of the total internal failure cost). In project 2, the percentage of rework cost was $61.09 \%$ and the cost of scrap was $38.91 \%$ of its internal failure cost. Meanwhile, in project 3 , a higher portion of rework cost was identified $(72.73 \%$ of the total internal failure cost) and the rest of internal failure cost $(27.27 \%)$ was due to construction scrap.

External failure cost in this research mainly comprises of the costs to respond to clients' complaints during the commissioning process. Table 5 presents the quality management activities that should be covered by external failure costs and the planned costs of this category in the three surveyed projects. Table 5 also shows that no external failure costs were planned by the contractors of the three projects.

Table 5 Quality Management Activities Covered by External Failure Cost.

\begin{tabular}{|c|c|c|c|c|}
\hline Category & Elements & $\begin{array}{c}\text { Proj. } \\
1\end{array}$ & $\begin{array}{c}\text { Proj. } \\
2\end{array}$ & $\begin{array}{c}\text { Proj. } \\
\mathbf{3}\end{array}$ \\
\hline \multirow[t]{3}{*}{ Warranty } & Investigation due to client's complaint & $\mathrm{X}$ & $\mathrm{X}$ & $\mathrm{X}$ \\
\hline & Rework to respond client's complaint & $\mathrm{X}$ & $\mathrm{X}$ & $\mathrm{X}$ \\
\hline & Product replacement & $\mathrm{X}$ & $\mathrm{X}$ & $\mathrm{X}$ \\
\hline Claim & Claim handling & $\mathrm{X}$ & $\mathrm{X}$ & $\mathrm{X}$ \\
\hline Product Rejection & Replacement, handling, storage, disposal & $\mathrm{X}$ & $\mathrm{X}$ & $\mathrm{X}$ \\
\hline \multirow[t]{2}{*}{ Hidden Cost } & Unsuitable work specification & $\mathrm{X}$ & $\mathrm{X}$ & $\mathrm{X}$ \\
\hline & Client's complaint investigation & $\mathrm{X}$ & $\mathrm{X}$ & $\mathrm{X}$ \\
\hline
\end{tabular}

\section{Total Quality Cost}

Table 6 shows a summary of planned quality cost identified in the three surveyed projects, expressed in percentage of contract value. Quality cost, as previously mentioned, is the sum of preventive cost, appraisal cost, and failure cost. Project 3, which was carried out by a private company, had the highest 
total quality cost (3.822\% of contract value) compared to those of the two other projects carried out by a state owned company. It is also shown that with a higher total preventive and appraisal cost, project 3 had a lower internal failure cost compared to project 1 and project 2 . This seems to be in accordance with the theory that prevention and appraisal cost will be higher with the increase of planned quality improvements, while failure cost will decrease when quality is improved.

Table 6 Summary of Surveyed Projects' Planned Quality Cost (in \% of Contract Value).

\begin{tabular}{ccccc}
\hline No & Quality Cost Components & Project 1 & Project 2 & Project 3 \\
\hline 1 & Preventive Cost & $0.304 \%$ & $0.860 \%$ & $0.948 \%$ \\
2 & Appraisal Cost & $0.883 \%$ & $1.790 \%$ & $2.324 \%$ \\
3 & Internal Failure Cost & $1.350 \%$ & $1.028 \%$ & $0.550 \%$ \\
4 & External Failure Cost & - & - & - \\
\hline & Total Quality Cost & $\mathbf{2 . 5 3 7 \%}$ & $\mathbf{3 . 6 7 8 \%}$ & $\mathbf{3 , 8 2 2 \%}$ \\
\hline
\end{tabular}

\section{Discussion}

The above survey findings reveal that systematic quality costs planning and quality cost measurement, as a basis for continuous improvement, had not been given enough attention by the contractors. Although some budget had been allocated for certain quality management activities, several important activities were left out. Quality costs accounting was practically inexistent in each company's system. Quality costs were not specially analyzed and controlled but merely treated as an integrated item of the whole project's cost. This could indicate that quality costs measurement had not yet been adopted as one of the main means to evaluate and monitor the performance of the contractors' quality management system. This situation not seem to be uniquely found among contractors in Indonesia but a common condition of contractors in several countries. In Malaysia, for example, Al-Tmeemy, et al. [11] mentioned that the application of the cost of quality concept in the construction industry is relatively a new field of interest and that the economical sense of improving quality is not well understood. Difficulties in performing cost accounting due to the complexity of construction projects were mentioned as the major cause. Besides, there is, in general, a lack of contractors' awareness of the need for their quality management system's performance evaluation.

Activities covered by appraisal costs predominantly received the attention of the contractors compared to other quality management activities, while failure costs were given the least attention in their quality costs planning. This confirms the statement of BSI [12] cited in Aoieong [5] that, in line with the TQM 
philosophy, an increased awareness of the cost to the organization of quality failure led first to an increase in appraisal of product quality. More will be spent on prevention, as appraisal, together with investigation, pointed to elements where improvement could be made to product design/process/systems.

Difficulties in identifying planned quality costs were mainly encountered with regard to failure costs. These costs were apparently unanticipated and consequently data were not available. Another problem was pointed out by Aoieong [5] who mentioned that in the collection of quality costs, the most significant problem is that of measuring external failure costs and that the cost due to consequential losses is the most difficult one to measure. More arguments were offered by Love and Irani [6] stating that appraisal and prevention costs are unavoidable costs that must be borne by design and construction organizations if their products/services are to be delivered 'right' the first time. Failure costs, on the other hand, are almost avoidable in construction, as most originate from ineffective management practices.

\section{Conclusion}

Lack of data and difficulties to identify planned quality costs lead to the conclusion that although the large contractors that were surveyed in this research had set their quality management systems, quality costs measurement and planning were a relatively new concept to them. In the objective of continuous quality improvement, quality costs measurement and its use in evaluating quality management effectiveness should be given more attention. The complexity of a construction project may hinder the efforts to implement this concept but once a good quality cost accounting system has been set the benefit of quality measurement would be experienced by contractors in addressing their competitiveness improvement issues. A lot of work is still to be done by the contractors in order to set up a quality costs recording system that can serve as a basis for their quality improvement planning.

\section{References}

[1] Dale, B. \& Oakland, J.S., Quality Improvement through Standards, S. Thornes Publishers, England, UK, pp. 40, 43, 1994.

[2] Dale, B. \& Plunkett, J., Quality Costing, $3^{\text {rd }}$ ed., Gower Publishing Limited, Hampshire, England, UK, pp. 9, 27, 32, 38, 48, 53, 143, 1999.

[3] Feigenbaum, A.V., Total Quality Control, Harvard Business Review, 34(6), pp. 93-101, 1956.

[4] Crosby, P.B., Quality Assurance, McGraw Hill Custom Publishing, 1979. 
[5] Aoieong, R.T., Capturing Quality Costs of Construction Processes Using the Construction Process Model (CPCM), PhD Thesis, Department of Civil and Structural Engineering, The HongKong Polytechnic University, HongKong, 2004.

[6] Love, P.E.D. \& Irani, Z., A Project Management Quality Cost Information System for the Construction Industry, Information \& Management, 40, pp. 649-661, 2003.

[7] Abramsson, P., Edmark, S., Ewers, S., Falk, E., Ullmar, E. \& Josephson, P.E., Poor Quality Costs in Large Construction Companies: What Can be Learned from Other Industries?, The CRIOCM International Symposium on Advancement of Construction Management and Real Estate, http://www.irb.net.de/daten/iconda/CIB5838.pdf (10 September 2013).

[8] Tawfek, H.S., Mohammed, H.E.H. \& Abdel Razek, M.E., Assessment of the Expected Cost of Quality (COQ) in Construction Projects in Egypt Using Artificial Neural Network Model, HBRC Journal, 8, pp. 132-143, 2012.

[9] Lam, S.W., Low, C.M. \& Teng, W.A., ISO 9000 in Construction, McGraw-Hill Book Co., pp. 21, 1994.

[10] Abdul Rahman, H., The Cost of Non-Conformance During a Highway Project: A Case Study, Construction Management and Economics, 13, pp. 23-32, 1995.

[11] Al-Tmeemy, S.M.H., Abdul-Rahman, H. \& Harun, Z., Contractors' Perception of the Use of Costs of Quality System in Malaysian Building Construction Projects, International Journal of Project Management, 30(7), pp. 827-838, 2012. (doi:10.1016/j.ijproman.2011.12.001)

[12] BSI (British Standards Institution), BS 6143: Part 2 Guide to the Economics of Quality-Preventive, Appraisal and Failure Model, British Standards Publishing, 1990. 